Original Paper

\title{
Pengayaan Materi Olimpiade Fisika dan Pelatihan Penyelesaian Soal-Soal Olimpiade Fisika Bagi Guru dan Siswa di SMP Islam Terpadu Putra Mataram
}

\author{
Susilawati $^{1 *}$, A. Doyan ${ }^{1}$, M. Taufik ${ }^{1}$, M. Zuhdi ${ }^{1}$ \\ ${ }^{1}$ Program Studi Pendidikan Fisika, Fakultas Keguruan dan Ilmu Pendidikan, Universitas Mataram, Indonesia
}

DOI: $10.29303 /$ jpmpi.v2i1.334

Sitasi: Susilawati, et, al. (2019). Pengayaan Materi Olimpiade Fisika dan Pelatihan Penyelesaian Soal-Soal Olimpiade Fisika Bagi Guru dan Siswa di SMP Islam Terpadu Putra Mataram. Jurnal Pengabdian Magister Pendidikan IPA (JPMPI). (2) 1. pp. 34-36

*Corresponding Author: Susilawati, Program Studi Pendidikan Fisika, Fakultas Keguruan dan Ilmu Pendidikan, Universitas Mataram, Indonesia;

Email: wildanfkip@unram.ac.id

\begin{abstract}
Tujuan kegiatan Pengabdian pada Masyarakat ini adalah untuk meningkatkan kemampuan siswa SMP Islam Terpadu Putra Mataram dalam mengerjakan soal-soal olimpiade. Kegiatan ini dilakukan melalui tiga tahapan yaitu , tahap persiapan, tahap pelaksanaan, dan tahap evaluasi. Secara umum, pelaksanaan kegiatan Pembinaan Olimpiade IPA Fisika SMP Islam Terpadu Putra Mataram berjalan dengan baik. Hal ini ditandai dengan meningkat minat siswa dalam mengikuti pembinaan, siswa bersemangat dalam mengikuti setiap pembinaan, siswa sangat aktif mengerjakan soal-soal Olimpiade yang diberikan oleh Pembina. Berdasarkan hasil wawancara dengan peserta kegiatan pelatihan diperoleh data bahwa kegiatan ini sangat bermanfaat karena telah memberikan pengalaman bagi siswa terkait bentuk soal-soal Olimpiade. Peserta sangat berharap kegiatan pembinaan tersebut dapat dilaksanakan di waktu yang lain
\end{abstract}

Keywords: Olimpiade IPA Fisika; Pembinaan; Soal-soal.

\section{Pendahuluan}

Kesiapan para siswa belum optimal dan masih mengalami banyak kendala dalam menghadapi Olimpiade IPA fisika, demikian halnya wawasan para guru pembimbingnya. Belum semua guru pembimbing olimpiade familiar dengan karakteristik dan perkembangan soal-soal olimpiade fisika. Olimpiade fisika Kabupaten/Kota, khususnya bidang fisika merupakan bentuk kegiatan rutin yang di selenggarakan oleh tiap Kabupaten/Kota hingga provinsi secara nasional, untuk dapat diikutkan dalam kompetisi olimpiade internasional (Doyan, 2019).

SMP Islam Terpadu Putra Mataram dalam rangka menangkap peluang tersebut, maka perlu mempersiapkan siswa-siswinya dalam mengikuti kegiatan tersebut. Dalam upaya mempersiapkan siswa, SMP Islam Terpadu Putra Mataram hendaknya guru pembimbing olimpiade terlebih dahulu diberikan pelatihan dan pembinaan khususnya guru pembimbing olimpiade fisika, sebab hingga saat guru pembimbing olimpiade belum pernah diberikan pelatihan dan pembinaan. Sehingga, guru pembimbing olimpiade fisika hingga saat ini belum mendalami materi dan mengenal ragam soal beserta cara pemecahannya. Oleh sebab itu, sangat diperlukan pelatihan dan pembinaan guru pembimbing olimpiade fisika agar lebih memahami trend soal-soal beserta penyelesaiannya dan pengayaan materi fisika tingkat SMP.

Pelatihan dan pembinaan ini diharapkan dapat meningkatkan kualitas pembimbingan oleh Guru untuk para siswa-siswi SMP Islam Terpadu Putra Mataram sehingga menjadi lebih baik dan dapat meningkatkan kesiapan para siswa mengikuti Olimpiade fisika. Hal ini yang menyebabkan kegiatan ini muncul, karena pihak sekolah menginginkan pembinaan dan pelatihan yang di sajikan oleh pengajar yang lebih fokus dan lebih memahami persoalan fisika. 


\section{Metode Pelaksanaan}

Menindak lanjuti keterbatasan dan kesulitan yang dialami guru-guru di SMP Islam Terpadu Putra Mataram dalam melakukan pembinaan olimpiade fisika terhadap siswa-siswi berbakat di bidang ilmu fisika maka disusunlah kerangka pemecahan masalah yang terbagi menjadi beberapa tahapan, yaitu: tahap persiapan, tahap pelaksanaan, dan tahap evaluasi.

Tahap persiapan dilakukan dalam bentuk identifikasi permasalahan-permasalahan atau kesulitan-kesulitan yang dialami oleh guru pembimbing olimpiade IPA fisika SMP Islam Terpadu Putra Mataram. Permasalahanpermasalahan yang telah diidentifikasi selanjutnya akan dicarikan alternatif-alternatif pemecahan yang paling memungkinkan dan paling tepat sesuai dengan karakter guru dan siswa yang ada di SMP Islam Terpadu Putra. Tahap pelaksanaan meliputi pelatihan dan bimbingan guru pembimbing olimpiade di SMP Islam Terpadu Putra Mataram akan dilaksanakan dalam waktu satu bulan. Selanjutnya bimbingan kepada siswa yang akan dilakukan oleh guru pembimbing akan dipantau oleh dosen. Proses pemantauan dilakukan sebagai upaya untuk memantapkan kemampuan guru dalam membimbing siswa-siswinya dalam menyelesaiakan soal-soal olimpiade fisika. Tahap evaluasi dilaksanakan untuk mengidentifikasi kekurangan-kekurangan dari pelaksanaan pembimbingan dan pelatihan. Evaluasi juga dilaksanakan pada kemampuan siswa dalam menyelesaikan berbagai bentuk soal-soal olimpiade (Doyan 2018).

\section{Hasil dan Pembahasan}

Kegiatan sosialisasi dan pendampingan Bentuk kegiatan Pembinaan Olimpiade IPA Fisika di SMP Islam Terpadu Putra Mataram adalah pertemuan berbentuk tambahan pelajaran. Pertemuan dilakukan sekali dalam seminggu. Pertemuan berlangsung selama empat jam. Dalam tiap jam diberikan latihan-latihan soal IPA Fisika, khususnya soal-soal yang setingkat Olimpiade Nasional. Soal-soal seperti ini bukanlah soal-soal yang biasa ditemukan untuk ujian semesteran maupun ujian akhir. Soal-soal Olimpiade tingkat SMP/MTs justru hampir menyamai soal-soal setingkat siswa SMA/MA.

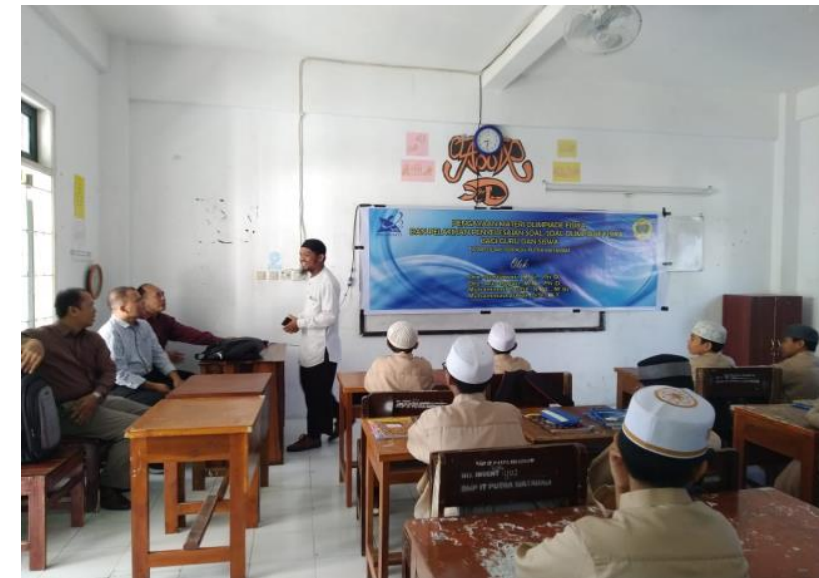

Gambar 1. Foto tahap persiapan pembinaan olimpiade oleh tim pembina

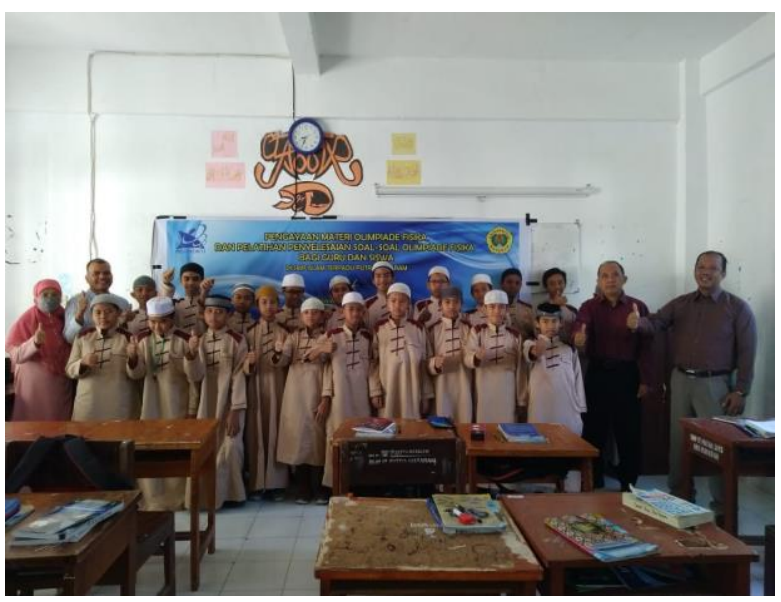

Gambar 2. Foto tim pembina dan siswa yang mengikuti pembinaan olimpiade

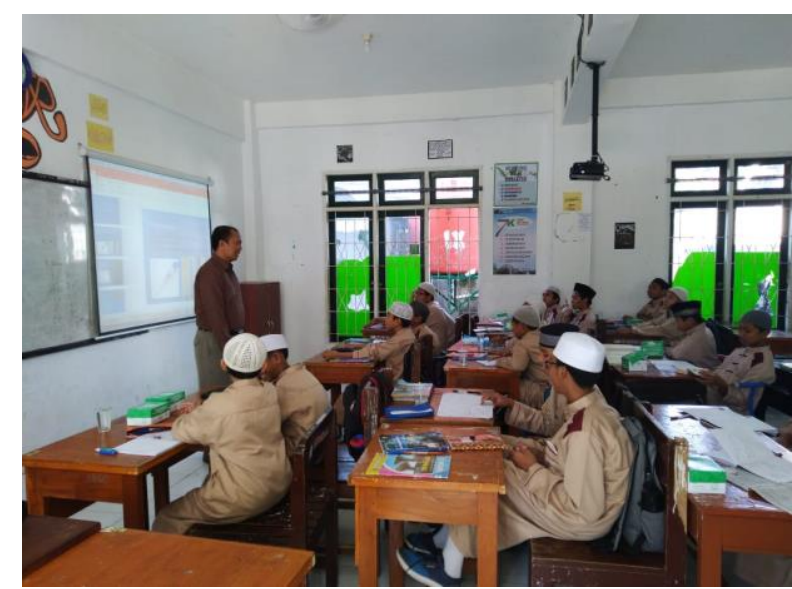

Gambar 3. Foto kegiatan pembinaan olimpiade oleh tim pembina

Secara umum, pelaksanaan kegiatan Pembinaan Olimpiade IPA Fisika berjalan dengan baik. Tiap pertemuan diisi dengan berbagai latihan soal IPA Fisika terutama soal-soal Olimpiade. 
Adapun tiap pertemuan diisi dengan kegiatan sebagai berikut: setiap siswa diminta untuk mengerjakan berbagai macam soal Olimpiade secara mandiri maupun bekerjasama dengan teman sebangku. Hal ini dilakukan selama kurang lebih 60 menit. Dalam setiap pertemuan diusahakan agar siswa-siswa tersebut dapat mengerjakan tiga sampai lima soal-soal Olimpiade IPA Fisika. Selanjutnya pembina membahas satu sampai dua soal. Untuk membahas satu buah soal Olimpiade IPA Fisika tidaklah sederhana karena memang tingkatannya tinggi. Satu soal membutuhkan sekitar tiga puluh menit untuk dibahas dengan baik. Pembahasan soal menjadi penting sekali agar siswa-siswa menjadi paham untuk mengerjakan soal-soal lain yang sejenis.

Salah satu indikator yang penting dalam kompetisi Olimpiade IPA Fisika adalah terbiasa mengerjakan soal-soal setingkat SMA/MA. Salah satu tujuan pembinaan ini adalah menumbuhkan intuisi agar siswa dapat beradaptasi dengan cepat dengan berbagai soal yang berbeda. Selain itu, tujuan lain dari pembinaan ini adalah untuk membiasakan siswa-siswa dengan soal Olimpiade.Selama pembinaan berlangsung, respon dari siswa cukup baik. Siswa bersemangat dalam mengikuti setiap pembinaan. Siswa sangat aktif mengerjakan soal-soal Olimpiade yang diberikan oleh pembina. Banyak pula pertanyaan-pertanyaan yang diajukan oleh siswa baik ketika mengerjakan soal-soal maupun ketika pembina memberi penjelasan tentang soal tertentu. Respon dari guruguru juga cukup baik. Guru-guru sangat mendukung adanya pembinaan ini, terutama dalam hal mensukseskan tiap-tiap pertemuan. Guru juga menentukan ruang mana yang dapat digunakan untuk pembinaan. Pada akhirnya, tidak semua siswa yang mengikuti pembinaan ini akan diajukan untuk mengikuti kompetisi Olimpiade IPA Fisika.

\section{Kesimpulan}

Secara keseluruhan,pembinaan olimpiade IPA fisika di SMP Islam Terpadu Putra Mataram ini telah berjalan dengan baik dan mencapai tujuannya, para peserta baik guru maupun siswa mendapat pengalaman dan pengetahuan dalam menghadapi olimpiade fisika di tingkat SMP. Dengan hasil kegiatan pembinaan olimpiade yang baik ini, maka perlu dilanjutkan di masa yang akan datang.

\section{Saran}

Pengayaan dan pelatihan materi olimpiade ini sudah berjalan dengan lancar, namun dalam kegiatan hendaknya disajikan media pembelajaran untuk membantu siswa agar materi menjadi konkret.

\section{Ucapan Terima Kasih}

Tim pengabdian mengucapkan terima kasih kepada kementerian riset, teknologi, dan pendidikan tinggi yang telah membiayai kegiatan pengabdian ini.

\section{Daftar Pustaka}

Anonim. 1991. Kamus Besar Bahasa Indonesia Edisi II. Jakarta : Balai Pustaka. 2005.

Doyan, A., Susilawati, Soeprianto,H., Bahri, S. 2018. Pelatihan Olimpiade MIPA Bagi Guru dan Peserta Didik SMA Kesuma Mataram. Jurnal Pengabdian Magister Pendidikan IPA 2018, (1) $1: 20-23$.

Kisi-kisi Olimpiade Sains Tingkat SMP. Jakarta: Depdiknas. 